\title{
Immediate reconstruction with autogenous graft after removal of recurrent ameloblastoma, treated 8 years previously
}

\author{
Reconstrução imediata com enxerto autógeno \\ após a remoção de ameloblastoma recorrente, tratado há 8 anos \\ Reconstrucción inmediata con injerto autólogo después de la eliminación de \\ ameloblastoma recurrente tratados durante 8 años \\ João Paulo BONARDI ${ }^{1}$ \\ Tiago Gai AITA ${ }^{2}$ \\ Valthierre Nunes DE LIMA ${ }^{1}$ \\ Thiago Henrique MARTINS ${ }^{2}$ \\ Cecilia Luiz PEREIRA-STABILE ${ }^{2}$ \\ Glaykon Alex Vitti STABILE ${ }^{2}$ \\ Eduardo HOCHULI-VIEIRA ${ }^{1,3}$ \\ ${ }^{1}$ Departamento de Cirurgia e Clínica Integrada, Faculdade de Odontologia de Araçatuba, \\ UNESP-Univ Estadual Paulista, Araçatuba - SP, Brasil \\ ${ }^{2}$ Departamento de Medicina Oral e Odontologia Infantil da Clínica Odontológica Universitária, \\ Universidade Estadual de Londrina, COU/UEL, Londrina-PR, Brasil. \\ ${ }^{3}$ Departamento de Diagnóstico e Cirurgia, Faculdade de Odontologia de Araraquara \\ UNESP-Univ Estadual Paulista, Araraquara-SP, Brasil
}

\begin{abstract}
Ameloblastoma is the most common benign odontogenic tumor of the jaw, being most frequently found in the mandible, especially in the body and branch regions. The treatment depends on the aggressiveness of the lesion and if not properly treated, can result in significant morbidity. The objective of this study is to report the case of a 29-yearold patient with a history of ameloblastoma which had been enucleated, recurring after 8 years of evolution. The tumor recurrence was treated through mandibular resection and reconstruction with an iliac crest bone graft. The patient is being monitored and is currently post-operative 50 months, showing no signs of recurrence to date. Ameloblastomas are lesions which present unpredictable behavior and thus require close monitoring irrespective of the treatment.

Descriptors: Ameloblastoma; Mandibular Neoplasms; Odontogenic Tumors.
\end{abstract}

\begin{abstract}
Resumo
Ameloblastoma é o tumor odontogênico benigno mais comum dos maxilares, sendo mais frequentemente encontrado na mandíbula, especialmente nas regiões do corpo e ramo. O tratamento depende da agressividade da lesão e se não tratada adequadamente, pode resultar em morbidade significativa. O objetivo deste estudo é relatar o caso de uma paciente de 29 anos com uma história de ameloblastoma que tinha sido enucleado, retornando depois de 8 anos. A recorrência do tumor foi tratado através de ressecção mandibular e reconstrução com enxerto de crista ilíaca. O paciente está sendo monitorado e atualmente encontra-se com um pós-operatório de 50 meses, não mostrando sinais de recidiva até o momento. Ameloblastomas são lesões que apresentam um comportamento imprevisível e, portanto, requerem um acompanhamento rigoroso, independentemente do tratamento.
\end{abstract}

Descritores: Ameloblastoma; Neoplasias Mandibulares; Tumores Odontogênicos.

\section{Resumen}

El ameloblastoma es el tumor odontogénico benigno más común de las mordazas, y se encontró con mayor frecuencia en la mandíbula, especialmente en las regiones del cuerpo y rama. El tratamiento depende de la agresividad de la lesión y si no se trata adecuadamente, puede dar lugar a una significativa morbilidad. El objetivo de este estudio es dar a conocer el caso de una paciente de 29 años con antecedentes de ameloblastoma que habían sido enucleado, regresando después de ocho años. La recidiva del tumor fue tratado mediante resección y reconstrucción mandibular con injerto óseo de cresta ilíaca. El paciente está siendo monitoreado y actualmente está con un postoperatorio de 50 meses, sin signos de recidiva hasta la fecha. Ameloblastomas son lesiones que tienen un comportamiento impredecible y por lo tanto requieren una vigilancia estrecha, independientemente del tratamiento. Descriptores: Ameloblastoma; Neoplasias Mandibulares; Tumores Odontogénicos.

\section{INTRODUCTION}

Ameloblastoma is the most common benign odontogenic tumor of the jaw and is of great clinical significance ${ }^{1}$. The principle characteristics are slow growth, an absence of symptoms and the presence of cortical bone expansion. It is most commonly found in the mandible, especially in the body and branch regions and is often diagnosed due to increased local volume or by means of routine radiographs ${ }^{2}$.

According to the histological classification of odontogenic tumors of the World Health Organization ${ }^{3}$, there are four types of ameloblastomas with distinct clinical and histological characteristics: solid or multicystic 
ameloblastoma; unicystic ameloblastoma; desmoplastic ameloblastoma and extraosseous or peripheral ameloblastoma.

Several factors may be used to determine the most appropriate treatment. One of the most important factors is the aggressiveness of the lesion, while other aspects to be observed prior to surgery are the anatomical location of the lesion, tumor size and extent, duration of the lesion and possible post-surgery reconstruction methods ${ }^{4}$.

If not properly treated ameloblastomas can result in significant morbidity ${ }^{5}$. Thus, a mandibular segmental resection followed by immediate reconstruction of the defect should be considered the treatment of choice for large mandibular ameloblastoma, provided that suitable bone remains to perform the technique ${ }^{2}$.

The objective of this study is to report a case of ameloblastoma which was initially treated conservatively and recurred after 8 years of evolution.

\section{CASE DESCRIPTION}

A male patient, 29 years old, attended the University Dental Clinic of the State University of Londrina, reporting the removal of a tumor from the face 8 years previously (Figure 1) and that the region where the tumor had been located was increasing in volume again.
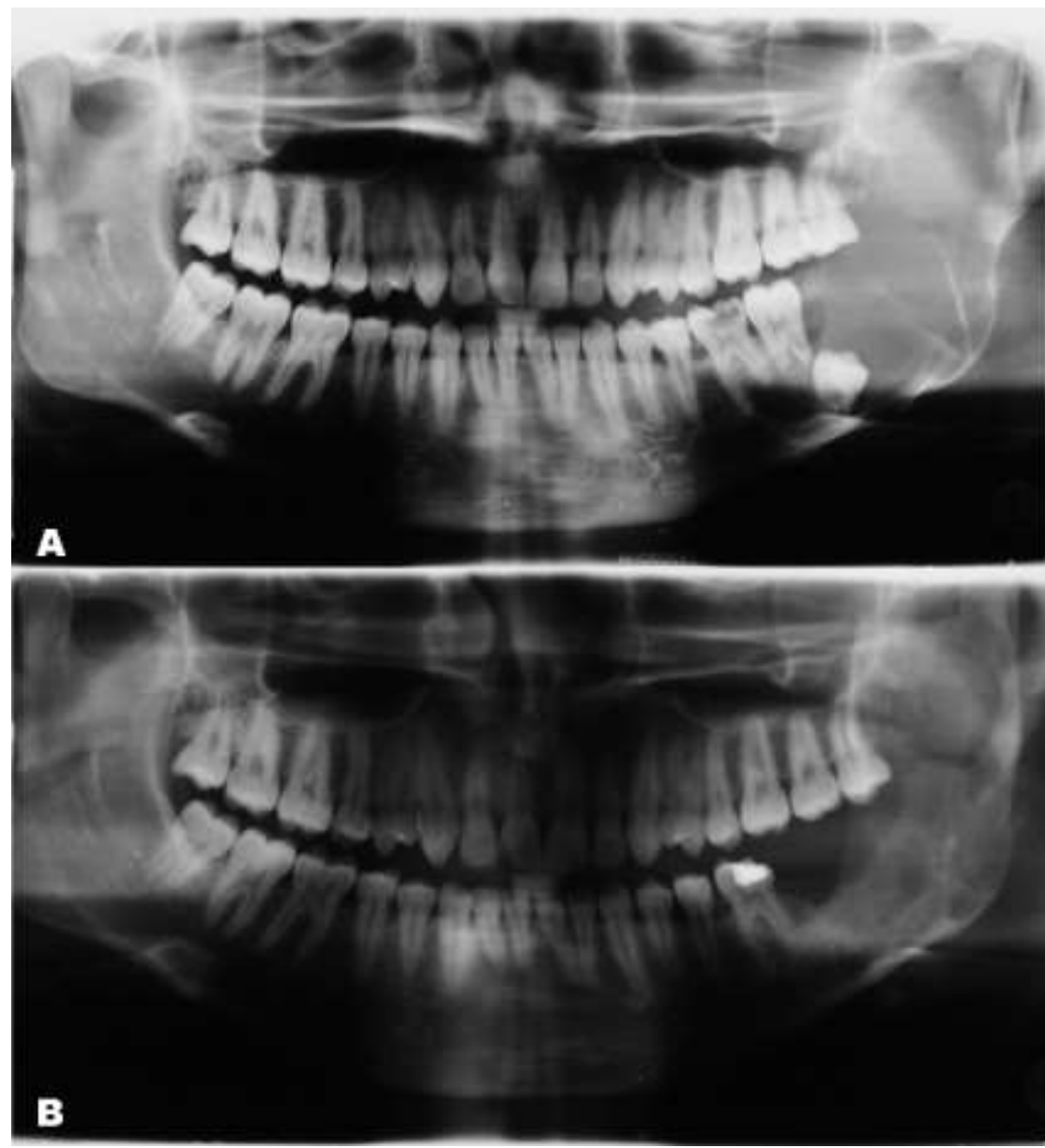

Figure 1: A) a panoramic radiograph performed in 2004, with tooth 38 impacted associated with a radiolucent image that also involves teeth

36,37 and the body angle and branch of the left mandibular;

B) 7 months postoperative, after enucleation of the lesion, showing an image suggestive of bone neoformation.

The patient presented the histopathological report of the excisional biopsy that was performed in 2004, where the diagnosis was a unicystic ameloblastoma. During the anamnesis, the patient did not report any allergies, habits or comorbidities. In the extraoral clinical examination a mild facial asymmetry was noted with bulging in the region of the left angle of the mandibular and in the intraoral examination, erythematous lesions associated with a bulging in the branch region of the left mandibular were identified (Figure 2). Access to the patient's records was obtained, reporting that in 2004 a unicystic ameloblastoma was diagnosed in the body, angle and branch regions of the left mandibular. This had been treated with exodontia of teeth 37 and 38 , associated with the injury, followed by enucleation and curettage. The patient was followed-up for 7 months with good evolution; however he had then abandoned the controls. Due to the history and clinical examination, a CT scan was requested which presented a hypodense image with cortical bone expansion and involvement, occupying the body, angle and branch regions of the left mandibular (Figure 3).

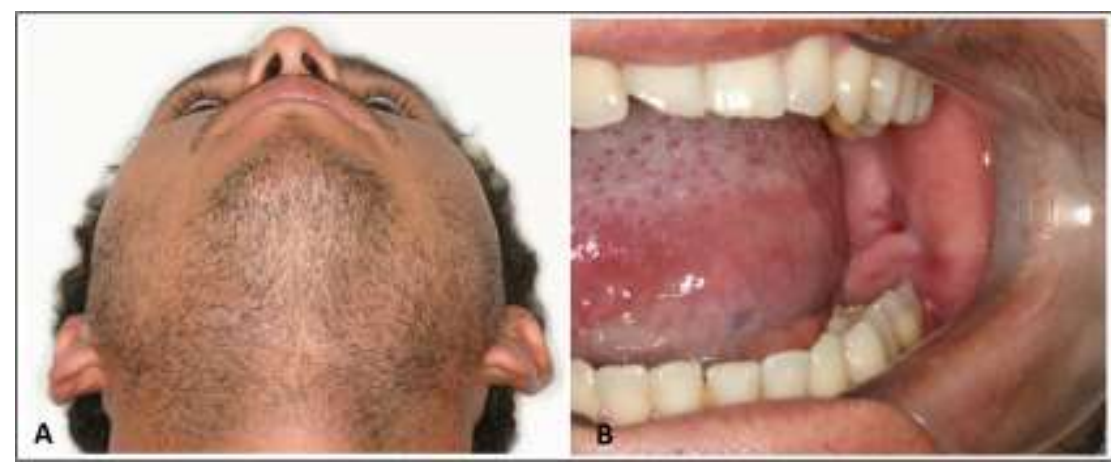

Figure 2: A) extraoral clinical examination, where slight facial asymmetry was noticed with bulging of the left mandibular angle region;

B) intraoral clinical examination, where erythematous lesions were noticed associated with a bulging of the left mandibular branch region.

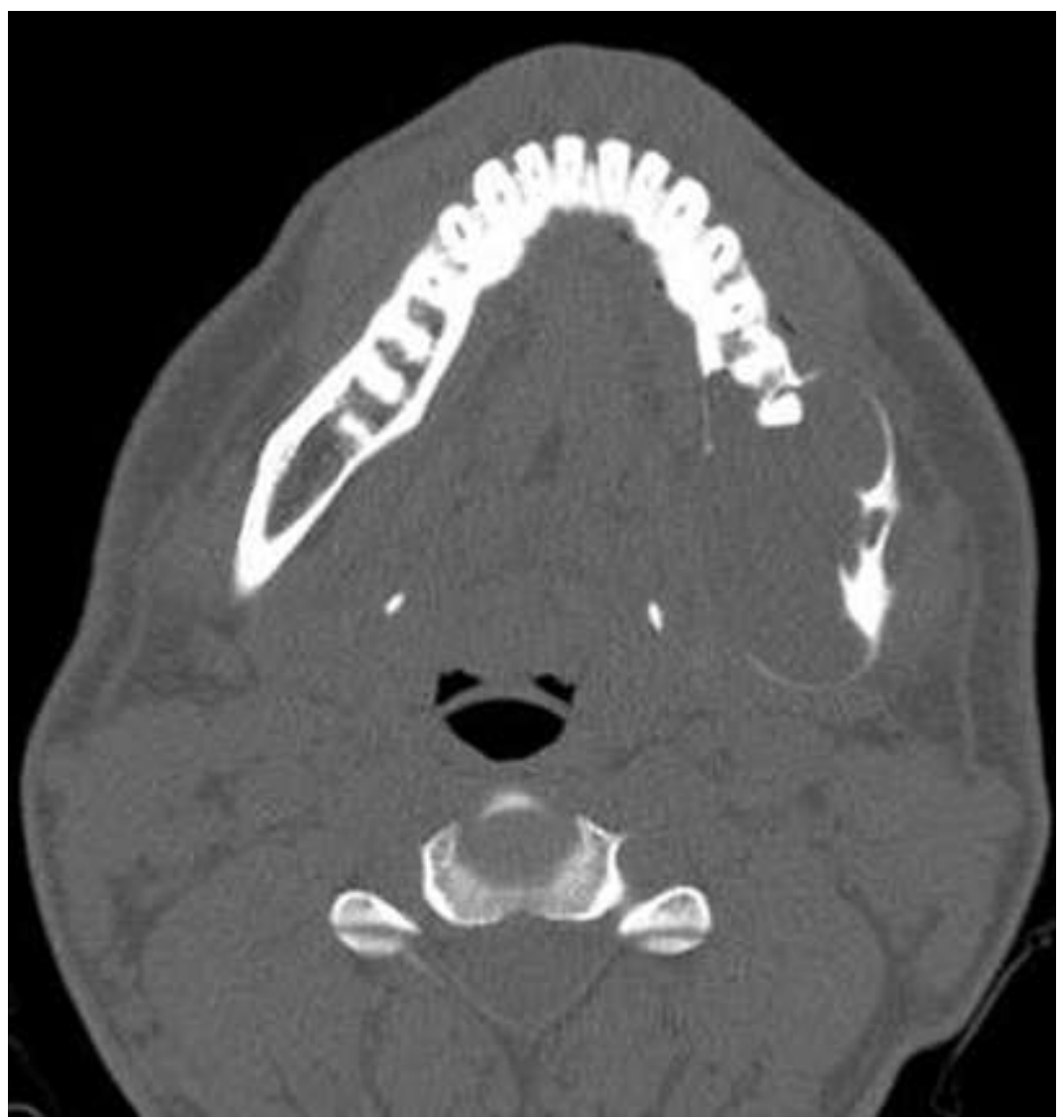

Figure 3: Axial computed tomography image showing hypodense with expansion and cortical bone involvement, occupying the body, angle and branch regions of the left mandibular.

Exodontia of teeth 35 and 36 was performed, associated with the lesion, and an incisional biopsy of soft and bone tissue. The pieces were sent for histopathological analysis and the report was consistent with plexiform ameloblastoma. For the treatment of the patient, tumor resection with immediate reconstruction was planned, using an autogenous graft from the anterior iliac crest. Prototypes of the jaw were requested, prepared free of charge by the Renato Archer Center for Information Technology (CIT), using the technique of rapid prototyping from tomographic images for better planning and pre-shaping of the fixing material (reconstruction plate 2.4 system) to be used during surgery. The patient underwent the surgical procedure under general anesthesia with tracheal intubation; transcervical access was chosen for better exposure of the lesion. To 
maintain the occlusion, an Erich bar was installed preoperatively and a maxillomandibular block performed prior to resection. This was followed with corticotomy for adaptation of the reconstruction plate of the pre-formed 2.4 system and its installation, followed by resection of the lesion with a safety margin of $1 \mathrm{~cm}$ (Figure $4 \mathrm{ABC}$ ). Concomitantly, the orthopedic team removed the tricortical anterior iliac crest graft from the patient and, after forming the graft, it was positioned in the bone gap while the plate, which was already in position, was fixed (Figure $4 \mathrm{D}$ ). This was followed by removal of the maxillomandibular block to check the occlusion and posterior suture of the access site. During the resection of the lesion there was communication with the oral cavity which was sutured immediately and the patient evolved to postoperative within normal limits. The patient has currently been postoperative for 50 months, presenting a radiographic image that suggests preservation of the mandibular bone structure (Figure 5). He is still followed-up by our team every six months and has presented no signs of recurrence to date.

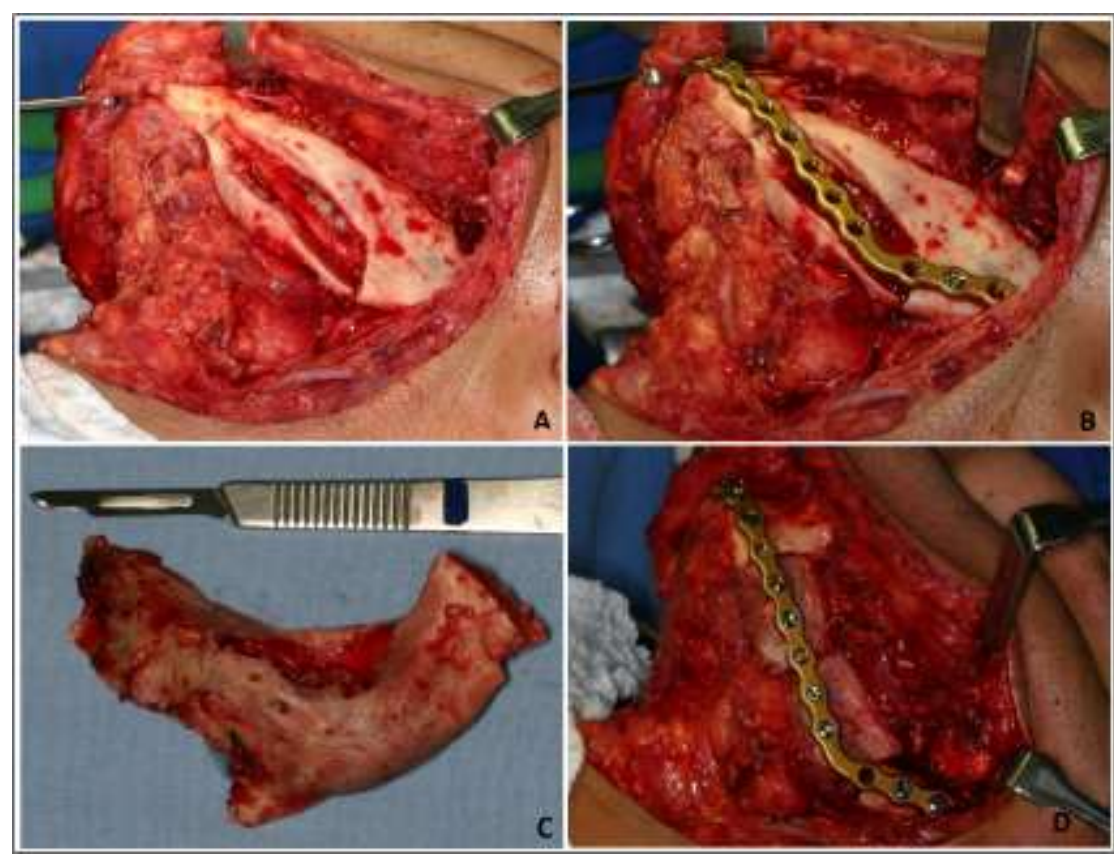

Figure 4: A) corticotomy for the adaptation of the 2.4 reconstruction plate system;

B) reconstruction plate installation; C) resected lesion; D)adaptation and installation of the autogenous anterior iliac crest graft.

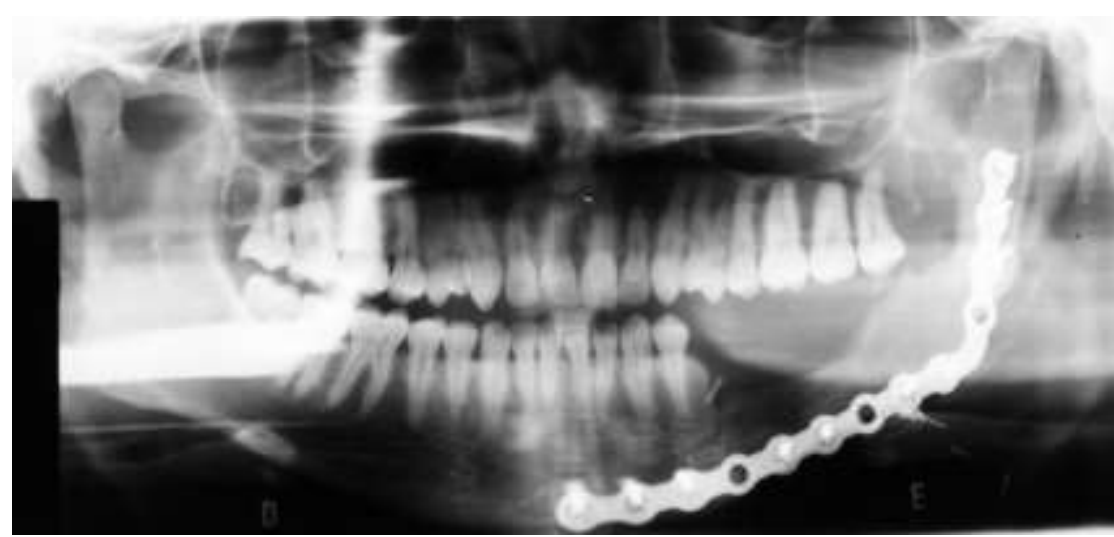

Figure 5: Panoramic radiograph 50 months postoperatively. The image suggests maintenance of the jaw line without recurrence of the lesion.

\section{DISCUSSION}

Ameloblastoma is the most common odontogenic tumor of epithelial origin, characterized by a diversity of clinical subtypes, great infiltration capacity and a high probability of recurrence ${ }^{1}$. Despite these characteristics some lesions are submitted to conservative treatment, especially the unicystic type ${ }^{6}$. In the reported case, conservative treatment was initially performed as the lesion was believed to be a unicystic ameloblastoma.

There are two schools of thought regarding the treatment of ameloblastoma. The most conservative school prioritizes removal of the disease without mutilation, not pursuing the target of free bone margins. The more aggressive school aims at complete removal of the disease with free bone margins, even if a bone defect is likely as a result of therapy. There is no consensus in the literature regarding which type of treatment should be used in ameloblastoma treatment. The clinical and radiographic characteristics, added to the result of the histopathological examination, guide the surgeon in deciding on the treatment $^{7,8}$.

About half the cases of ameloblastoma exhibit a multilocular aspect, always radiolucent, with clearly defined sclerotic margins, with internal septa and standard soap bubbles or honeycombs due to the numerous compartments of varying sizes limited by bony septa. The loculations can be oval or rounded, with varying dimensions?

The lesions are characteristically expansive, and may have scalloped edges (well defined in most cases), pierce cortical bone and invade soft tissues ${ }^{1}$. Frequent radiographic findings are: septation, association with impacted teeth, resorption of roots, rotations and displacement of neighboring teeth and vestibule lingual cortical expansion more likely than with cysts 9 . Despite the patient presenting fenestration and intimate contact with the masseter muscle, there were no complications, since the part of the muscle that communicated with the injury was also removed together with the bone.

Although some authors believe that ameloblastomas should not be treated conservatively, the literature is replete with studies containing this type of approach. However, inadequate postoperative follow-up does not clearly support this conclusion. Due to the scarcity of evidence on long-term success, at best, the treatment should be based on clinical, radiographic and histological findings ${ }^{10}$. Corroborating with the literature, even in cases of minor injuries, such as found in the patient in 2004, when multilocular images are presented, the lesion should be treated more aggressively.

When performing any treatment, whether conservative or radical, on a lesion with high potential for recurrence, long-term follow-up should be performed with at least one return visit per year, so that in the case of recurrence, treatment can be instituted as soon as possible. Singh et al, conducted a study on the therapeutic management of five cases of ameloblastoma, based on the radiographic appearance, histological type, size and location, however after treatment, each patient was accompanied for a minimum of ten years ${ }^{4}$.

Surgical resection involves the removal of the tumor with some healthy bone as a safety margin; it differs from conservative techniques through the absence of contact between the surgical instruments and the lesion. It is a technique derived from the treatment of malignant lesions, applied to invasive and recurrent cancers ${ }^{11}$. The advantages of resection are: a greater chance of successful treatment in the case of recurrent diseases and the possibility of histopathological examination of the perilesional tissue. The disadvantages presented by the technique are: tooth loss, injury to adjacent structures, increased surgical size and the need for rehabilitation procedures ${ }^{8}$. Since this was a recurrence eight years after the first intervention, we decided to accept the difficulties of rehabilitation and establish aggressive treatment in order to reduce the chances of a further relapse.

Segmental mandibular resection, followed immediately by reconstruction of the defect should be considered as the treatment of choice for large mandibular 
ameloblastomas, as this approach achieves the best functional and aesthetic results, with less potential for recurrence. There are several options for bone reconstruction after tumor resection. The most common include the use of $2.4 \mathrm{~mm}$ titanium reconstruction plates associated with autogenous bone grafts, which may be free or microvascularized; the most frequently used donor sites are the anterior iliac crest, rib and fibula ${ }^{2}$ Thus, immediate bone reconstruction, for the purpose of eliminating a second surgery to reconstruct the post-surgical defect, was performed as, during the planning process, it was observed that the surgery would leave a critical defect.

\section{CONCLUSION}

Ameloblastomas are lesions with unpredictable behavior which require strict monitoring, independent of the treatment instituted, due to the aggressive behavior of recurrent lesions which ultimately lead patients to mutilating treatments and difficult reconstructions.

\section{REFERÊNCIAS}

1. Ghandhi D, Ayoub AF, Pogrel MA, MacDonald G, Brocklebank LM, Moos KF. Ameloblastoma: a surgeon's dilemma. J Oral Maxillofac Surg. 2006; 64(7):1010-4.

2. Bianchi B, Ferri A, Ferrari S, Leporati M, Copelli C, Ferri $\mathrm{T}$, et al. Mandibular resection and reconstruction in the management of extensive ameloblastoma. J Oral Maxillofac Surg. 2013; 71(3):528-37.

3. Gardner DG, Heikinheimo K, Shear M, Philipsen HP, Coleman H. Ameloblastomas. In: Barnes L, Eveson JW, Reichart P, Sidransky D. World Health Organization Classification of Tumors. Pathology \& Genetics of Head and Neck Tumours. Lyon: IARC Press; 2005. p. 296300 .

4. Singh M, Shah A, Bhattacharya A, Raman R, Ranganatha N, Prakash P. Treatment algorithm for ameloblastoma. Case Rep Dent. 2014:121032.

5. Herford AS, Boyne PJ. Reconstruction of mandibular continuity defects with bone morphogenetic protein-2 (rhBMP-2). J Oral Maxillofac Surg. 2008; 66(4):616-24.

6. Antonoglou GN, Sándor GK. Recurrence rates of intraosseous ameloblastomas of the jaws: a systematic review of conservative versus aggressive treatment approaches and meta-analysis of non-randomized studies. J Craniomaxillofac Surg. 2015; 43(1):149-57.

7. Kim SG, Jang HS. Ameloblastoma: a clinical, radiographic, and histopathologic analysis of 71 cases. Oral Surg Oral Med Oral Pathol Oral Radiol Endod. 2001; 91(6):649-53.

8. Nakamura N, Mitsuyasu T, Higuchi Y, Sandra F, Ohishi M. Growth characteristics of ameloblastoma involving the inferior alveolar nerve: a clinical and histopathologic study. Oral Surg Oral Med Oral Pathol Oral Radiol Endod. 2001; 91(5):557-62.

9. Sachs SA. Surgical excision with peripheral ostectomy: A definitive, yet conservative, approach to the surgical management of ameloblastoma. J Oral Maxillofac Surg. 2006; 64(3):476-83.

10. George J, Kamboj M. Ameloblastoma - An enigma. J Oral Biol Craniofac Res. 2012; 2(3):203-5.

11. Takahashi K, Miyauchi K, Sato K. Treatment of ameloblastoma in children. Br J Oral Maxillofac Surg. 1998; 36(6):453-6.

\section{CONFLICTS OF INTERESTS}

The authors declare no conflicts of interests.

\section{CORRESPONDING AUTHOR}

João Paulo Bonardi

joao_bonardi@hotmail.com

Received 20/10/2016

Accepted 25/10/2016 